\title{
PELAKSANAAN SUPERVISI KEPALA SEKOLAH SD NEGERI 11 KAMPUNG BARU
}

\author{
Nola Refika, Rahmadini, Vadly Ermansyah, Zelly Susanti \\ Peneliti Independen Manajemen Pendidikan Islam IAIN Batusangkar \\ e-mail: Nolarefika14@gmail.com
}

\begin{abstract}
In this qualitative study, the researchers described the implementation of supervision by the principal in State Primary School 11 Kampung Baru, Batusangkar. The data in this study were from the principal and the teachers. The result revealed that the supervision activities by the principal in State Primary School 11 Kampung Baru include 1) planning; 2) actuating; and 3) funding.
\end{abstract}

Keywords: Supervision, Principal, State Primary School 11, Batusangkar.

\section{PENDAHULUAN}

Penelitian tentang supervisi oleh Kepala Sekolah terhadap peningkatan kualitas kinerja guru dan tenaga kependidikan perlu di kaji. Ada beberapa alasan di antaranya, pertama, karena jika dilihat realita yang ada pada saat ini, yaitu era globalisasi di mana semuanya serba digital, akses informasi sangat cepat dan persaingan hidup semakin ketat, dan bangsa Indonesia harus meningkatkan sumber daya manusia. Hanya bangsa yang mempunyai sumber daya manusia yang unggul yang dapat bersaing dan mempertahankan diri dari dampak persaingan global yang ketat. Termasuk sumber daya pendidikan.

Salah satu sumber daya pendidikan adalah tenaga pendidik dan kependidikan. Pengembangan sumber daya manusia memiliki pengaruh sangat penting bagi kesuksesan dan kesinambungan pembangunan. Oleh karena itu pembangunan dan peningkatan kualitas sumber daya manusia mutlak diperlukan. Dalam konteks pembangunan sumber daya manusia pendidikan pada dasarnya merupakan proses mencerdaskan kehidupan bangsa dan pengembangan manusia Indonesia seutuhnya, dijelaskan dalam Sisdiknas pasal 3 Bab 3 (2003: 5) "bahwa pendidikan nasional berfungsi mengembangkan kemampuan dan membentuk wadah serta peradaban bangsa yang bermartabat dalam rangka mencerdaskan kehidupan bangsa, bertujuan untuk berkembangnya potensi peserta didik agar menjadi manusia yang beiman dan bertakwa terhadap Tuhan Yang Maha Esa berakhlak mulia sehat berilmu, cakap, kreatif, mandiri dan menjadi warga Negara yang demokratis dan bertanggungjawab".

Mengingat betapa pentingnya pendidikan dalam mencerdaskan kehidupan bangsa, selain faktor Kepala Sekolah yang 
cukup memegang pengaruh penting dalam pencapaian prestasi belajar siswa, ada juga pengaruh dari kinerja mengajar guru. Pentingnya kinerja mengajar dalam meningkatkan prestasi belajar siswa yang optimal, merupakan salah satu kekuatan internal yang dapat digunakan untuk meningkatkan kualitas peserta didik. Guru merupakan penentu keberhasilan pendidikan melalui kinerjanya pada tataran intitusional dan eksperiensial, sehingga upaya meningkatkan mutu pendidikan harus dimulai dari aspek "guru" dan tenaga kependidikan lainnya yang menyangkut kualitas keprofesionalannya maupun kesejahteraan dalam satu manajemen pendidikan yang profesional.

Kedua, yaitu berupa permasalahan yang dihadapi dalam melaksanakan supervisi di lingkungan pendidikan dasar terkait bagaimana cara mengubah pola pikir yang bersifat otokrat dan korektif menjadi sikap yang konstruktif dan kreatif, yaitu sikap yang menciptakan situasi dan relasi di mana guruguru merasa aman dan diterima sebagai subjek yang dapat berkembang sendiri. Untuk itu supervisi harus di laksanakan berdasarkan data, fakta yang objektif (Sahertian, 2010: 20).

Ketiga, yaitu karena perkembangan kurikum dan pengembangan tenaga pendidik dan tenaga kependidikan perlu dilakukan agar tercapainya tujuan sekolah yang berdampak pada prestasi sekolah. Hal ini dapat tercapai juga jika diadakan supervisi oleh kepala sekolah terhadap guru dan tenaga kependidikan tersebut.

Maka, untuk meningkatkan sumber daya guru bisa dilaksanakan dengan bantuan supervisor. Dalam hal ini supervisor yaitu Kepala Sekolah berperan sebagai supervisor dalam meningkatkan kulitas sumber daya guru dan tenaga kependidikan di suatu sekolah sehingga tercapai prestasi dan tujuan yang ditetapkan.

Setelah melakukan observasi dan wawancara awal di SD Negeri 11 Kampung Baru, menurut peneliti pengaruh supervisi akademik terhadap kinerja guru dan staf penting untuk di kaji. Penelitian ini di lakukan atas dasar 1) SD Negeri 11 Kampung Baru merupakan sekolah pertama di Tanah Datar yang menerapkan kurikulum 2013 dan masih berlanjut sampai saat ini; 2) SD Negeri 11 Batusangkar terletak di pusat Kota dan dikenal oleh masyarakat sebagai sekolah yang berkualitas; 3) SD Negeri 11 Kampung Baru sering mewakili Sumatera Barat dalam berbagai ajang perlombaan; 4) SD Negeri 11 Kampung Baru menjadi pilihan utama bagi wali murid untuk mendaftarkan anaknya pada tingkat Sekolah Dasar; 5) SD Nergeri 11 Kampung Baru dulu disebut dengan SD teladan karena meraih 
berbagai prestasi yang membanggakan dan disiplin yang tinggi; 6) SD Negeri 11 Kampung Baru merupakan SD yang sudah tua di Batusangkar yang berdiri sejak tahun 1996 dan didirikan oleh masyarakat dan wali murid dengan gotong royong; 7) SD Negeri 11 Kampung Baru adalah SD yang dikategorikan sudah maju, hal ini dapat dilihat dari fasilitas dan ruangan yang ada serta lingkungan yang bersih.

\section{METODE PENELITIAN}

Penelitian ini merupakan penelitian dengan menggunakan metode kualitatif. Metode penelitian kualitatif dipilih karena peneliti bermaksud untuk mendeskripsikan dan menganalisis fenomena tertentu secara mendalam dan terperinci. Metode penelitian kualitatif menurut Sugiyono (2012: 1) adalah Metode penelitian yang digunakan untuk meneliti pada kondisi obyek yang alamiah, (sebagai lawannya adalah eksperimen) di mana peneliti adalah sebagai instrumen kunci, teknik pengumpulan data dilakukan secara trianggulasi (gabungan), analisis data bersifat induktif dan hasil penelitian kualitatif lebih menekankan makna dari pada generalisasi.

Penelitian ini dilakukan untuk mendeskripsikan dan menganalisis supervisi yang di lakukan oleh Kepala Sekolah pada tenaga pendidik di SD Negeri 11 Kampung
Baru, khususnya terkait dengan kompetensi Kepala Sekolah tersebut. Sehingga, pada kegiatan mengumpulkan, mengungkapkan, berbagai masalah dan tujuan yang akan dicapai, maka penelitian ini dilakukan dengan pendekatan studi deskriptif analitik. Penelitian deskriptif menurut Zuriah (2009: 47) adalah "penelitian yang diarahkan untuk memberikan gejala-gejala, fakta-fakta, atau kejadian-kejadian secara sistematis dan akurat, mengenai sifat-sifat populasi atau daerah tertentu". Metode kualitatif dengan pendekatan studi deskriptif analitik yang digunakan dalam penelitian ini untuk menjelaskan bagaimana kondisi kompetensi Kepala Sekolah dalam melakukan kegiatan supervisi di SD Negeri 11 Kampung Baru, di mana teknik dalam mengumpulkan data yaitu dengan cara wawancara, observasi dan studi dokumen.

\section{HASIL PENELITIAN DAN PEMBAHASAN}

Berdasarkan dokumentasi yang diperoleh di SD Negeri 11 Kampung Baru bahwa dalam Kepala Sekolah melaksanakan program supervisi dengan terstruktur, diawali dengan perencanaan, pelaksanaan kegiatan belajar mengajar, penilaian dan tindak lanjut.

\section{Perencanaan}

Dalam perencanaan supervisi yang dilakukan oleh Kepala Sekolah dalam 
membuat penilaian kepada guru tekait hal-hal sebagai berikut.

a. Merencanakan pengelolaan pembelajaran, yang meliputi; 1) merumuskan kompetensi dasar dan indikator, 2) menentukan metode pembelajaran, 3) menentukan langkahlangkah pembelajaran, 4) menentukan cara memotivasi siswa, 5) menentukan pengalaman belajar siswa, menentukan alokasi waktu, 6) menentukan alokasi waktu,

merencanakan pengorganisasian materi pembelajaran, 8) kesesuaian materi pembelajaran dengan kurikulum, 9) mengembangkan materi pembelajaran yang sesuai dengan perkembangan siswa;

b. Merencanakan pengelolaan kelas, meliputi 1) penataan ruang kelas, 2) pengorganisaian siswa aktif dalam pembelajaran.

c. Merencanakan penggunaan alat/media pembelajaran, meliputi 1) memilih sumber pembelajaran, 2) menentukan penggunaan alat/media pembelajaran.

d. Merencanakan penilaian, meliputi 1) menentukan bentu-bentuk proder dan teknik penilaian, 2) menyusun alat penilaian.

e. Penampilan fisik rencana pembelajaran, meliputi 1) penggunaan bahasa tulis, 2) kerapian dan kebersihan.

Dalam pelaksanaan pembelajaran yang dilakukan oleh Kepala Sekolah dalam menilai guru tekait hal-hal sebagai berikut.

a. Membuka kegiatan pembelajaran, meliputi; 1) menyampaiankan materi penggait/persepsi, 2) memotivasi sisa untuk memulai pembelajaran, 3) menyampaiakan kompetensi yang harus di capai siswa.

b. Mengelola kegiatan pembelajaran inti, meliputi 1) penguasaan materi pembelajaran, 2) memberi contoh/ilustras/analogi, menggunakan sumber, alat, media pembelajaran, 4) mengarahkan siswa untuk aktif berpartisipasi, 5) memberi penguatan, 6) melaksanakan kegiatan pembelajaran dengan urutan yang logis dan teratur, 7) merespon secara positif keinginan siswa, 8) menentuakan antusiasme/gairah mengajar.

c. Mengorganisasi waktu, siswa, sumber dan alat/media pembelajaran, meliputi 1) mengatur penggunaan waktu, 2) melaksanakan pengorganisasin siswa, 3) menyiapkan sumber dan alat bantu.media pembelajaran.

d. Melaksanakan penilaian, meliputi 1) melaksanakan penilaian proses, 2) melaksanakan penilaian hasil/akhir. 
e. Menutup kegiatan pembelajaran, meliputi 1) merangkum materi, 2) memberi tindak lanjut.

f. Penampilan guru, meliputi 1) kesan umum, 2) penampilan dan sikap guru dalam pembelajaran.

Dalam keterampilan melaksanakan hubungan pribadi yang dilakukan oleh Kepala Sekolah dalam menilai guru tekait hal-hal sebagai berikut.

a. Membantu mengembangkan perilaku positif pada diri murid, meliputi; 1) membantu murid untuk menyadari kekuatan dan kelemahan diri, 2) membantu murid untuk menumbuhkan kepercayaan pada diri sendiri, 3) membantu siswa untuk dapat mengekspresikan perasaan dan pikiran, 4) menunjukan simpati, dan 5) menunjukan keramahan dan menghargai orang lain.

b. Menampilkan kegairahan dan Kesungguhan dalam kegiatan pembelajaran, meliputi; 1)menunjukan kegairahan dalam pembelajaran, 2) memberi kesan menguasia materi, 3) menunjukan kemantapan mengajar.

c. Mengelola interaksi dalam kelas, meliputi; 1) mengembangkan hubungan antar pribadi yang sehat dan serasi, 2) menunjukan iklim belajar yang kondusif.
Dalam aktifitas siswa dalam pembelajaran yang dilakukan oleh Kepala Sekolah dalam menilai guru mengaktifkan siswa tekait hal-hal sebagai berikut 1) siswa antusias dalam mengikuti pembelajaran, 2) siswa menyimak ketika guru memberikan penjelasan, 3) siswa mengajukan pertanyaan pada saat yang tepat, 4) siswa tidak canggung bertanya dan mengajukan pendapat, 5) siswa melakukan aktivitas sesuai dengan pengalaman belajar yang di rencanakan, 6) siswa menunjukan keinginan untuk menguasai materi dan 7) siswa berbahasa dengan baik dan benar.

Berdasarkan hasil penelitian tersebut dapat dilihat bahwa perencanaan kegiatan supervisi kelas di SD Negeri 11 Kampung Baru sudah terencana dengan baik dan terstruktur. Dalam perencanaan tersebut dimulai dari rencana pembelajaran, pelaksanaan pembelajaran, keterampilan dalam melaksanakan hubungan pribadi dan aktifitas siswa dalam pembelajaran. Hal itu di rencanakan secara matang oleh SD Negeri 11 Kampung Baru untuk tercapainya proses pembelajaran yang efektif, sehingga tercapainya tujuan pembelajaran khususnya dan tujuan sekolah umumnya.

\section{Pelaksanaan}

Kegiatan Supervisi kelas di SD Negeri 11 Kampung Baru dilaksanakan 
secara terprogram yang meliputi kelas I, II, III, IV, V, VI dengan harapan seluruh guru kelas dan guru mata pelajaran dapat melengkapi segala rencana yang telah di tetapkan sebelumnya. Agar pelaksanaan terorganisasi secara baik maka program ini dapat dilengkapi dengan jadwal pelaksanaannya. Setelah kegiatan dilaksanakan maka temuan yang di peroleh ditulis dalam program tindak lanjut yang akan dilaksanakan oleh guru kelas yang bersangkutan.

Berdasarkan hasil wawancara dengan Kepala Sekolah dapat diketahui bahwa, kegiatan supervisi kelas di SD Negeri 11 Kampung Baru sudah terjadwal dengan baik dan terlaksana sesuai dengan perencanaan Kepala Sekolah, hal ini terbukti dengan diraihnya prestasi-prestasi siwa tingkat Nasional dan bahkan rata-rata seluruh siswa adalah siswa berprestasi. Hal ini dikarenakan adanya kegiatan supervisi, karena dengan dilakukan pembinaan pada guru-guru maka guru akan lebih mudah dalam melaksanakan proses pembelajaran. Sehingga tercapai kegiatan pembelajaran yang efektif. Hal ini didukung oleh pendapat Asmendri (2012: 129) yang menyatakan bahwa supervisi kelas adalah bentuk supervisi yang difokuskan pada peningkatan mengajar dengan melalui siklus yang sistematik, dalam perencanaan, pengamatan, serta analisis yang intensif dan cermat tentang penampilan mengajar yang nyata, serta bertujuan mengadakan perubahan dengan cara yang rasional.

SD Negeri 11 Kampung Baru salah satu sekolah di Indonesia yang masih dipercaya untuk menerapkan Kurikulum 2013. Sewaktu peneliti menanyakan bentuk kegiatan supervisi oleh Kepala Sekolah terhadap perubahan kurikulum KTSP 2006 ke Kurikulum 2013, Kepala Sekolah menerangkan bentuknya yaitu berupa kunjungan kelas, seminar dan pelatihanpelatihan khusus untuk para guru. Karena awalnya guru masih bingung untuk menggunakan kurikulum ini. Namun setelah di lakukan pelatihan 3 bulan, guru sudah menguasai Kurikulum 2013, sehingga berlanjut sampai sekarang.

Peneliti juga menanyakan langsung kepada salah seorang guru SD tersebut bernama Irmawati. SPd.SD tentang kendala guru-guru dalam menerapkan Kurikulum 2013 dan bagaiamana peran Kepala Sekolah dalam hal tersebut. Beliau mengungkapkan bahwa "kendala yang ibu rasakan yaitu penilaian dalam Kurikulum 2013 sangat rumit, karena menilai siswa dari berbagai aspek dan tidak hanya memerhatikan aspek kognitif saja. Terkadang banyak guru yang keliru dengan penilaian ini. Namun dengan adanya kegiatan supervisi oleh Kepala Sekolah, ibu merasa terbantu sekali, ibu 
dapat menanyakan tentang format penilaian dan juga diberikan pelatihan khusus oleh Kepala Sekolah tentang penilaian ini”.

Kemudian, respon siswa terhadap Kurikulum 2013 sangat menyenangkan karena siswa lebih suka dalam pembelajaran mengunakan sarana seperti infokus, metode yang digunakan dalam pembelajaran pun cenderung metode diskusi. Hal ini sangat disukai siswa, karena siswa dapat berperan aktif dalam proses pembelajaran.

Kepala Sekolah SD Negeri 11 Kampung Baru tergolong sekolah unggul di Tanah Datar. Untuk tercapainya prestasi siswa ini tidak lepas dari motivasi yang diberikan oleh Kepala Sekolah kepada guruguru. Motivasinya berupa setiap guru diberi tugas dan kepercayaan masing-masing, contohnya untuk lomba IPA dan MTK diserahkan langsung ke guru bersangkutan dan teknik yang di gunakan pun juga di serahkan ke guru terssebut. Sewaktu kami melakukan wawancara dengan ibu Irmawati beliau mengatakan "ibu di percayakan oleh kepala sekolah dalam membina siswa untuk mengikuti lomba pidato dan cerita. Semuanya tergantung pada ibu untuk melatih siswa agar mendapatkan juara dan alhamdulilah berkat kepercayaan penuh dari Kepala Sekolah dan kerja keras SD Negeri 11 Kampung Baru mampu bersaing tingkat Nasional”.
Jika di tinjau pada proses pembelajaran, guru di SD tersebut sudah menerapkan pembelajaran yang transformatif, tidak transaksional. Hal ini di dukung oleh keterangan dari Dr Muhammad Kristiawan MPd (Perkuliahan Supervisi Pendidikan, 20 Mei 2016), yang mengatakan bahwa pembelajaran transformatif yaitu mengubah pola pikir, maka dia akan semakin baik dan kreatif berfikirnya dari tidak tau jadi tau, intinya di sini pada pembelajaran transformatif ini ada perubahan sehingga dapat mengubah tingkah laku individu ke hal yang lebih baik.

Dengan metode tersebut SD Negeri 11 Kampung Baru tahun ini mampu mewakili Sumatera Barat pada 3 cabang kegiatan yaitu 1) tari, 2) pidato, 3) cerita. Namun yang paling menonjol adalah cerita, karena 6 orang mewakili Sumatera Barat untuk lomba bercerita ini. Hal ini pun tentu tidak lepas dari kerja keras pihak sekolah dan juga siswa yang bersangkutan.

Selain supervisi yang dilakukan Kepala Sekolah, guru juga mempunyai teknik supaya anak/siswa pintar, yaitu diberi pembinaan untuk siswa yang bermasalah. SD Negeri 11 Kampung Baru jadwal pulang sekolah siswa tidak tepat waktu, karena diberikan pembinaan ekstra pada para siswa. Namun mata pelajaran yang paling susah bagi siswa adalah Matematika, pada 
pelajaran ini langkah dari pada guru yaitu memberikan siswa PR yang terjadwal $1 \mathrm{x}$ Sebulan dan 1 x 15 hari.

Kepemimpinan Kepala Sekolah juga sangat memempengaruhi dalam kegiatan supervisi di SD tersebut. Hal ini sesuai dengan pendapat Tim Dosen Administrasi Pendidikan Universitas Indonesia (2014: 125) yang memamparkan kepemimpinan berarti kemampuan dan kesiapan yang dimiliki oleh seseorang untuk dapat mempengaruhi, mendorong, mengajak, menuntun, menggerakkan, mengarahkan, dan kalau perlu memaksa orang atau kelompok akan menerima pengaruh tersebut dan selanjutnya berbuat sesuatu yang dapat membantu tercapainya suatu tujuan tertentu yang telah ditetapkan. Oleh karena itu, seorang pemimpin harus mampu menerapkan kepemimpinan yang efektif di suatu sekolah, agar mampu mempengaruhi, mengajak, menuntun, menggarahkan orang atau sekelompok orang untuk tercapainya tujuan yang telah di tetapkan.

Gaya kepemimpinan yang diterapkan Kepala sekolah menurut peneliti yaitu gaya kepemimpinan leziz feire dan demokratis, hal ini didukung oleh ungkapan ibu Irmawati SPd.SD Bahwa "Kepala Sekolah dalam mengambil keputusan mengunakan musyawarah dengan seluruh personil sekolah yang bersangkutan, namun dalam kegiatan pembelajaran dan perlombaan kepala sekolah tidak ikut campur mengenai metode dan cara dalam membimbing siswa, namun Kepala Sekolah menyerahkan secara langsung pada guru yang bersangkutan. Kepala Sekolah mempercayakan pada guru tersebut, hal ini di karenakan guru di SD tersebut sangat kreatif dan berkualitas dan kebanyak guru-guru senior yang sudah paham betul akan pola pengajaran yang efektif tersebut. Maka oleh karena itu peneliti menyimpulkan gaya kepemimpinan yang di terapkan Kepala Sekolah di SD tersebut demokrasi dan leziz feire.

Jika di tinjau tenaga kependidikan di SD tersebut, menurut ibu Irmawati SPd.SD, tenaga kependidikan yang baru tidak diberikan pelatihan oleh kepala sekolah. Namun disuruh untuk menyesuaikan dan bekerjasama dengan tenaga kependidikan yang lama. Hal ini menurut peneliti tidak bagus diterapkan, karena tenaga kependidikan juga sangat mempengaruhi untuk tercapainya tujuan pendidikan. Oleh karena itu mereka juga harus diperhatikan, dengan cara memberi pelatihan kepada sesuai dengan pekerjaannya. Ketika melakukan wawancara, peneliti melihat langsung, sewaktu tenaga kependidikan baru diberi tugas oleh Kepala Sekolah, dia kebingungan dan berulang kali menanyakan tentang tugas tersebut. Maka hal ini menurut peneliti 
Kepala Sekolah harus memberikan supervisi kepada tenaga kependidikan sehingga tercapai tujuan pendidikan.

SD Negeri 11 Kampung Baru menerapkan setiap guru memiliki visi dan misi tersendiri, yang di pajang di depan lokal masing-masing. Setiap guru memiliki visi dan misi berbeda, namun tujuannya tetap untuk tercapainya visi dan misi sekolah. Hal ini sangat mendukung tercapainya tujuan, karena sudah terstruktur dengan jelas dan dirumuskan oleh guru yang bersangkutan serta di setujui oleh Kepala sekolah.

Kegiatan supervisi di SD tersebut didukung oleh teknologi yang canggih. Kepala Sekolah dapat secara langsung mengawasi lingkungan sekolah, termasuk proses pembelajaran dan proses kegiatan kinerja pegawai sekolah serta lingkungan sekolah umumnya. Hal ini dikarenakan di ruangan Kepala Sekolah ada kamera CCTV untuk semua lingkungan sekolah.

Berdasarkan wawancara dan data yang peneliti yang diperoleh di atas, dapat simpulkan bahwa pelaksanaan supervisi Kepala Sekolah di SD Negeri 11 Kampung Baru sudah terlaksana dengan baik dan terprogram. Kepala Sekolah memberikan kepercayaan penuh kepada guru yang bersangkutan setelah diberikan pembinaan oleh Kepala Sekolah. Dengan begini, guru akan lebih bertanggungjawab, sehinga akan meningkatkan kualitas proses pembelajaran. Guru juga diberi tanggung jawab dalam membina siswa dalam mengikuti perlombaan, dengan pembinaan dan kepercayaan penuh dari Kepala Sekolah, SD Negeri 11 Kampung Baru mampu bersaing dan mewakili Sumatera Barat dalam berbagai ajang perlombaan.

Kegiatan supervisi di SD tersebut dapat terlaksana dengan baik ini disebabkan didukung oleh fasilitas yang disediakan, salah satunya CCTV. Dengan adanya CCTV di ruangan Kepala Sekolah ini, menurut peneliti dapat meningkatkan kinerja guru dalam mengajar dan akan tercipta disiplin yang tinggi serta unsur kejujuranpun akan diterapkan.

Kekurangan yang peneliti temukan terhadap kinerja Kepala Sekolah yaitu Kepala Sekolah hanya memperhatikan guru dalam kegiatan supervisi ini, namun kepala sekolah kurang memperhatikan tenaga kependidikan. Hal ini hendaknya kepala sekolah menyeimbangkan antara guru dan tenaga kependidikan karena keduanya sangat berkontribusi terhadap tercapainya tujuan pendidikan. Hal ini di pengaruhi karena gaya kepemimpinan laiziz fayre di terapkan. Untuk gaya ini juga bagus, namun tidak sesuai jika di terapkan untuk tenaga kependidikan yang baru. 


\section{Pendanaan}

Untuk terlaksananya program yang telah direncanakan, perlu ditunjang dengan dana yang cukup. Dana yang digunakan untuk pelaksanaan supervisi kelas ini adalah dana yang bersumber dari Bantuan Operasional Sekolah(BOS). Berdasarkan wawancara dan data yang peneliti peroleh di atas, dapat diketahui pendanaan untuk kegiatan supervisi ditunjang oleh dana yang cukup. Dana tersebut di ambil dari Bantuan Operasional Sekolah. hal ini sesuai dengan aturan penggunaan dana BOS itu sendiri, salah satunya untuk kegiatan pembinaan dan pelatihan yaitu kegiatan supervisi.

\section{KESIMPULAN}

Berdasarkan hasil penelitian dan pembahasan yang telah dikemukakan di atas dapat disimpulkan bahwa kegiatan supervisi Kepala Sekolah di SD Negeri 11 Kampung Baru di mulai dari perencanaan, pelaksanaan dan pendanaan. Dalam kegiatan pelaksanaan itu juga terdapat kegiatan tindak lanjut.

$\begin{array}{llllll}\text { Kegiatan supervisi di } & \text { SD } & \text { N } & 11\end{array}$ Kampung Baru sangat terstruktur dan jelas, dengan demikian kegiatan supervisi berjalan dengan sangat baik. Guru pun merasa terbantu dengan kegiatan supervisi Kepala Sekolah, contohnya dalam penilaian pada Kurikulum 2013. Dengan adanya kegiatan tersebut guru dapat memahami penilaian pada Kurikulum 2013 tersebut.

Pendanaan untuk kegiatan supervisi juga sangat jelas, yaitu bersumber dari dana Bantuan Operasional Sekolah (BOS). Dana BOS sudah cukup untuk terlaksananya kegiatan supervisi oleh Kepala Sekolah. Kepemimpinan yang diterapkan oleh Kepala Sekolah adalah demokrasi, namun yang peneliti dapatkan keterangan dari guru, mengarah kepada leziz feire. Kemudian kegiatan supervisi di SD Negeri 11 Kampung baru didukung oleh teknologi yang canggih, serta sarana dan prasarana yang lengkap.

\section{DAFTAR PUSTAKA}

Asmendri. (2012). Manajemen Peningkatan Mutu. Batusangkar: STAIN Batusangkar Press.

Tim Dosen Administrasi Pendidikan Universitas Pendidikan Indonesia. (2014). Manajemen Pendidikan. Bandung: Alfabeta.

Sahertian, A. Piet. (2010). Konsep Dasar dan Teknik Supervisi Pendidikan. Jakarta. Bumi Aksara.

Sugiyono. (2012). Metode penelitian kuantitatif, kualitatif, dan $R \& D$. Bandung: Alfabeta.

Undang-Undang Sisdiknas No. 20 Tahun 2003

Zuriah, N. (2009). Metodologi Penelitian Sosial dan Pendidikan: Teori dan Aplikasi. Jakarta: Bumi Aksara. 